\title{
Controlled Laboratory System to Study Soil Solarization and Organic Amendment Effects on Plant Pathogens
}

\author{
Eyal Klein, Jaacov Katan, Miriam Austerweil, and Abraham Gamliel
}

First, third, and fourth authors: Laboratory for Pest Management Research, Institute of Agricultural Engineering, ARO, The Volcani Center, Bet Dagan 50250, Israel; and first and second authors: Department of Plant Pathology and Microbiology, The Hebrew University of Jerusalem, Faculty of Agricultural, Food, and Environmental Quality Sciences, Rehovot 76100, Israel.

Accepted for publication 18 June 2007.

\begin{abstract}
Klein, E., Katan, J., Austerweil, M., and Gamliel, A. 2007. Controlled laboratory system to study soil solarization and organic amendment effects on plant pathogens. Phytopathology 97:1476-1483.

A controlled laboratory system for simulating soil solarization, with and without organic amendment, was developed and validated using physical, chemical, and biological parameters. The system consists of soil containers that are exposed to controlled and constant aeration, and to temperature fluctuations that resemble those occurring during solarization at various depths. This system enables a separate analysis of volatiles and other components. We recorded a sharp decrease in oxygen concentration in the soil atmosphere followed by a gradual increase to the original concentration during solarization in the field and heating in the simulation
\end{abstract}

ABSTRACT system of soil amended with wild rocket (Diplotaxis tenuifolia) or thyme (Thymus vulgaris). The combined treatment of organic amendment and solarization (or heating in the controlled system) was highly effective at controlling populations of Fusarium oxysporum f. sp. radicis-lycopersici. Changes in soil $\mathrm{pH}$, enzymatic activities, and microbial populations followed, in most cases, trends which were similar under both solarization and the heating system, when exposed to controlled aerobic conditions. The reliability and validity of the system in simulating physical, chemical, and biological processes taking place during solarization is demonstrated.

Additional keywords: biological control, herb residues, pest management.
Soil solarization is a nonchemical approach for soil disinfestation that results in pathogen control either directly through physico-thermal killing, or indirectly by the stimulation of antagonistic activity (22) or by weakening of the pathogen resting structures in soil, thus exposing them to antagonistic microorganisms (14). Organic amendments (OA) are incorporated in soil in order to control soilborne pathogens; it is widely documented that plant debris containing glucosinolates can generate biologically active products in the soil and control plant pathogens (6). Application of OA and solarization, alone or in combination, can alter the chemical, physical, and biological properties of the soil and consequently result in pathogen control and disease suppression. Ramirez-Villapudua and Munnecke (30) reported that solar heating of soil amended with cabbage residues eliminated Fusarium oxysporum f. sp. conglutinans; under laboratory conditions, heating and OA decreased total fungi by about $20 \%$, and bacterial population was increased 16-fold by gases arising from decomposing cabbage residues in soil in closed containers. Solarization of soil amended with chicken compost effectively controlled Meloidogyne incognita and Pythium ultimum (18). The rhizosphere of lettuce plants grown on solarized soils was intensively colonized by fluorescent pseudomonads and Bacillus spp. and lettuce yield was increased in successive fall and spring (18). Different herbs contain essential oils that consist of terpenes, phenols, alcohols, and organic acids, some of which are biocides $(26,35)$. The combination of herb residues and solarization has the potential to improve pest control and expand its spectrum of activity $(15,17)$.

Corresponding author: A. Gamliel; E-mail address: agamliel@agri.gov.il

doi:10.1094/PHYTO-97-11-1476

(C) 2007 The American Phytopathological Society
Solarization is a climate-dependent method. Therefore, its studies can be carried out only during a limited period of the year, usually lasting 2 to 4 months, and only under natural field conditions. A laboratory controlled system which reliably reproduces the temperature fluctuations and accompanying processes which take place in the soil could enhance solarization research, especially when combined with OA. Several studies on simulated solarization have been reported $(17,19,30,38)$. However, those systems did not fully emulate all of the processes occurring in the soil. For example, aeration was not controlled in these systems. The objectives of the present study were to develop a controlled laboratory system for the simulation of soil solarization, alone or in combination with $\mathrm{OA}$, and to examine the reliability of this system by comparing physical, chemical, and biological parameters to those obtained under field conditions.

\section{MATERIALS AND METHODS}

Soil and OA. Agricultural sandy soil from Rehovot (94\% sand, $2 \%$ silt, $4 \%$ clay, and $0.14 \%$ organic matter, $\mathrm{pH} 7.9$; field capacity [measured at $-33 \mathrm{~J} / \mathrm{Kg}$ matric potential] of $12 \%$ ) was used for the field and laboratory experiments. Rehovot soil represents a wide range of agricultural soils in Israel with high sand content and low organic matter (36).

Fresh leaves and stems of Diplotaxis tenuifolia L. (wild rocket) and Thymus vulgaris L. (thyme) were collected from commercial herb fields and were air-dried at $25^{\circ} \mathrm{C}$. The dried material was ground and passed through a 2-mm sieve for the laboratory experiments, or through a 5-mm sieve for the field trials. In the controlled laboratory system, the dried material was mixed with soil $\left(1 \%, \mathrm{wt} / \mathrm{wt}\right.$, which is equivalent to a rate of $1 \mathrm{~kg} / \mathrm{m}^{2}$ in the field) and was wetted to water-holding capacity.

A controlled system for soil heating and application of organic amendment. A semi-open controlled-environment system 
was developed to emulate the physical, chemical, and microbial changes that take place in the field soil during solarization, with or without the addition of OA (Fig. 1). The controlled system consisted of soil containers in which the soil-OA mixture was incorporated ( $2 \mathrm{a}$ in Fig. 1). The soil containers (2 liter volume) were immersed in a water bath which was heat-regulated by a micro-logger (21X, Campbell Scientific Inc., Logan, UT) and immersion thermostat circulator (Fried Electric, Haifa, Israel) to achieve the temperature regimes that prevail in soil at a depth of $20 \mathrm{~cm}$ during solarization in the summer in Israel. The soil containers were designed to allow air flow from the bottom of the containers through the soil, and to channel the volatile compounds that may be generated to a second container ( 0.5 liter volume) ( $2 \mathrm{~b}$ in Fig. 1). The second container was placed outside the water bath, at room temperature. Each of the two containers was sealed with a glass lid and a screw ring. The lid in each container had two ports, each controlled by a gas-tight valve (Elchem Plastic, Kibbutz Baraam, Israel). Polyvinylchloride tubing (10 mm diameter, $5 \mathrm{~mm}$ wall thickness) connected the containers to a diaphragm air pump (Charles Austen Pumps Ltd., Byfleet, UK) (3a in Fig. 1). The pump compressed air to each container via a 2-liter manifold (3b in Fig. 1), in order to supply uniform air flow to each container. The air flow through each soil container was regulated by dosing disks, with 0.008 -in $(0.203 \mathrm{~mm})$ aperture diameter (Spraying Systems Co., Wheaton, IL), which were mounted at the end of each volatile-exposure container (3c in Fig. 1). The air flow was regulated by a gas-tight valve (Elchem Plastic) in the manifold and was monitored by a gas-flow meter (J\&W Scientific, Folsom, CA). The pressure in the system was adjusted to 60 to $70 \mathrm{~Pa}(<0.001$ bar $)$ and was monitored by connecting a 0 - to 200-Pa pressure meter (Micatrone, Solna, Germany). A rubber septum was installed at the top of each container lid and used to draw samples of volatile compounds. A second wide port ( $32 \mathrm{~mm}$ diameter) was installed in the wall of the soil container and used to withdraw soil samples during the incubation period.

Anaerobic conditions in amended soil were tested in the containers in a second set of containers. The anaerobic conditions were created by connecting the soil containers and the volatileexposure containers in a closed and sealed circuit without air circulation. This set was also placed in the water bath under the same temperature conditions as the other containers.

Field studies. Two field experiments were carried out during the summer of 2002, at the experimental farm of the Hebrew University in Rehovot. The soil was rotavated to $50 \mathrm{~cm}$ depth and was then irrigated to water-holding capacity down to $50 \mathrm{~cm}$. Plots ( 2 by $2 \mathrm{~m}$ ) were outlined in a randomized block design, with three replicates for each treatment. Dried leaves and stems of thyme and wild rocket were manually spread over the soil surface of separated plots at a rate of $1 \mathrm{~kg} / \mathrm{m}^{2}$, and were incorporated by rototilling down to $25 \mathrm{~cm}$ depth. Tubing for gas sampling (nylon 11; $5 \mathrm{~mm}$ inside diameter, $5 \mathrm{~m}$ long) was placed at depths of 20 and $40 \mathrm{~cm}$ in plots, with or without $\mathrm{OA}$ and with or without solarization, in order to draw $\mathrm{O}_{2}$ and determine its concentration in the soil atmosphere. The buried end of each tubing was wrapped with a cylinder of plastic netting $(10 \mathrm{~cm}$ long by $15 \mathrm{~mm}$ diameter) thus creating a headspace to avoid clogging of the air flow. The other end of the tubing was extended outside of the plots and was connected to the $\mathrm{O}_{2}$-measuring system. An open plastic pipe, $50 \mathrm{~mm}$ diameter, was placed in each plot at a depth of $20 \mathrm{~cm}$, with the other end extending outside the plot on the soil surface and sealed with a gas-tight cap. Soil samples were withdrawn through this pipe from each plot during the experiment, avoiding the need to pull out the plastic mulch. Inocula of the tested soilborne pathogens were wrapped in nylon-mesh bags, and were buried in the center of each plot at the indicated depths. Trenches (40 cm deep) were cut in the margins of each plot, and amended and nonamended plots were mulched with a transparent polyethylene sheet (100 $\mu \mathrm{m}$ thick). Nonsolarized plots were similarly mulched but were shaded with a $90 \%$ shading screen (Polysak, Nir Itzhak, Israel) which was placed over the plastic mulch to prevent soil heating. The plots were solarized for a period of 4 weeks during July or August. Soil temperatures were measured at depths of 20,30 , and $40 \mathrm{~cm}$, using type-T thermocouples (accuracy $\pm 0.5^{\circ} \mathrm{C}$ ) that were connected to a micrologger (21X, Campbell Scientific Inc.). The same device was used to measure the temperature in the soil and headspace in the controlled laboratory system.

Measurement of oxygen concentration. Oxygen sensors (Clark-Almemo, Hudson, MA) connected to a micrologger were used to determine $\mathrm{O}_{2}$ concentration in the soil atmosphere by circulating the soil atmosphere from the tested sample through the sensor for 6 min using diaphragm air pumps (Charles Austen Pumps Ltd.). Oxygen concentration was calculated from a calibration curve by mixing $\mathrm{N}_{2}(99.999 \%)$ and $\mathrm{O}_{2}(99.99 \%)$ at known rates in a specially designed mixing cylinder. The output reading was also verified by a portable oxygen monitor, HGA-11-B (Emproco Ltd., Ashkelon, Israel).

Soil pH. Soil pH was determined essentially as described by Conn and Lazarovits (9). Soil (3 g) from each replicate (soil container or field plot) was added to a tube containing $15 \mathrm{ml}$ of bidistilled water and shaken at maximal speed by Vortex-Genie (Scientific Industries Inc., Springfield, MA) for $30 \mathrm{~s}$. The soil suspension was incubated at $25^{\circ} \mathrm{C}$ for $30 \mathrm{~min}$; $\mathrm{pH}$ level was then determined with a $\mathrm{pH}$ electrode (Thermo Russel, Auchtermuchty Fife, Scotland).

Assessment of viability of soilborne plant pathogens and microbial populations. Naturally infested soil containing chlamydospores of Fusarium oxysporum f. sp. radicis-lycopersici Jarvis \& Shoemaker was collected from Zohar Experimental Station in Ein-Tamar, southeast Israel. The inoculum was put in nylon-net bags (325 Mesh) and was wetted to water-holding capacity $24 \mathrm{~h}$ before use. Galled tomato roots, containing eggs and larvae of Meloidogyne javanica, collected from a tomato greenhouse in the Habesor region, were kept fresh with the soil attached in a wet chamber at $4^{\circ} \mathrm{C}$ for up to 1 week and were chopped and mixed $(1 \%$, wt/wt) with Rehovot soil at waterholding capacity. In laboratory experiments, the nematode-soil mixture $(1.7 \mathrm{~kg})$ was put in the soil containers and used for the treatments; in field experiments, $300 \mathrm{~g}$ of the mixture was used as infested soil.

Changes in populations of total bacteria, fungi, and $F$. oxysporum f. sp. radicis-lycopersici were determined in soil samples

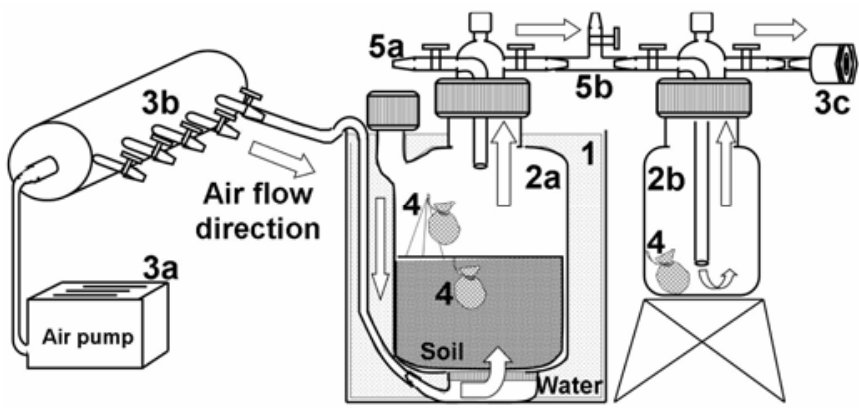

Fig. 1. A semi-open controlled-environment system for soil treatment and exposure of pathogens to varying heating and aeration regimes. (1) Water bath for heat regulation with water-circulation system. (2a) A special glass soil container, 2 liter volume, which enables air flow from the bottom of the container through the soil and out to a volatile-exposure container. (2b) Volatile-exposure container, 0.5 liter volume, placed outside the bath, at room temperature. (3a) Diaphragm pump pushes air through a 2-liter manifold (3b) which enables uniform air flow in each container. (3c) Dosing disks for airflow regulation. (4) Exposure of test pathogens to different control factors at different container sites. Connections to $\mathrm{O}_{2}$ sensor (5a) and pressure monitor (5b). 
of the treated soil by soil dilution (16). A 2.5-g soil sample from each replicate was mixed with $23.5 \mathrm{ml}$ of sterile water agar $(0.1 \%$, $\mathrm{wt} / \mathrm{vol})$ containing $\mathrm{MgSO}_{4} \cdot 7 \mathrm{H}_{2} \mathrm{O}(0.1 \%$, wt/vol) and shaken for $45 \mathrm{~min}$ in a reciprocal shaker (200 rpm); serial dilutions were then made and aliquots of $0.2 \mathrm{ml}$ for fungi and $0.1 \mathrm{ml}$ for bacteria were spread on four petri dishes containing appropriate medium: modified Peptone-Rose Bengal (11) (in which $0.25 \mathrm{~g}$ of chloramphenicol per liter was used instead of streptomycin) for total fungi, and a modified Fusarium-selective agar medium based on peptone and pentachloronitrobenzene (16) for $F$. oxysporum and King's B medium (23) for bacteria. Randomly chosen isolates of $F$. oxysporum were tested for pathogenicity using tomato seedlings in order to verify their identity as $F$. oxysporum $\mathrm{f}$. sp. radicis-lycopersici. Plates were incubated in the dark at $27^{\circ} \mathrm{C}$ for 4 to 6 days. Results are expressed as colony forming units (CFU) per gram of soil (dried at $105^{\circ} \mathrm{C}$ for $48 \mathrm{~h}$ ). Treated soil, which was infested with $M$. javanica, was transferred to pots in a greenhouse $\left(25 \pm 2^{\circ} \mathrm{C}\right)$. Tomato seedlings were planted in these pots and grown for 30 days. The plants were then uprooted, washed, and rated for galling. Results were expressed as percentage of plants with root galls.

Sampling and analysis of volatile compounds. The atmosphere above the soil in the experimental containers was sampled and analyzed using solid-phase microextraction (SPME) and gas chromatography $(1,20)$. The SPME device containing polydimethylsiloxane-coated fiber, $100 \mu \mathrm{m}$ thickness (Supelco Inc., Bellefonte, PA), was exposed for $45 \mathrm{~min}$ in the headspace through silicone rubber septa (Thermogreen LB-1, Supelco Inc.). After exposure, the SPME fiber was inserted into the injection port of a gas chromatograph (HP 589011, Hewlett Packard, Avondale, PA) fitted with a flame-ionization detector and a fused silica capillary column DB-5 ([5\% phenyl] methyl polysiloxane), $30 \mathrm{~m}$ long by $0.25 \mathrm{~mm}$ inside diameter, film thickness $0.25 \mu \mathrm{m}$ (J\&W Scientific, Folsom, CA). Temperatures of the injection port and the detector were 220 and $270^{\circ} \mathrm{C}$, respectively. Nitrogen $(99.999 \%)$ was used as the carrier gas at a flow rate of $1 \mathrm{ml} / \mathrm{min}$. The temperature program was as follows: initial temperature of $50^{\circ} \mathrm{C}$ for 5 min, raised at a rate of $4^{\circ} \mathrm{C}$ per min to the final temperatures of 190 or $220^{\circ} \mathrm{C}$, for nonheated and heated treatments, respectively.

Field $20 \mathrm{~cm}$

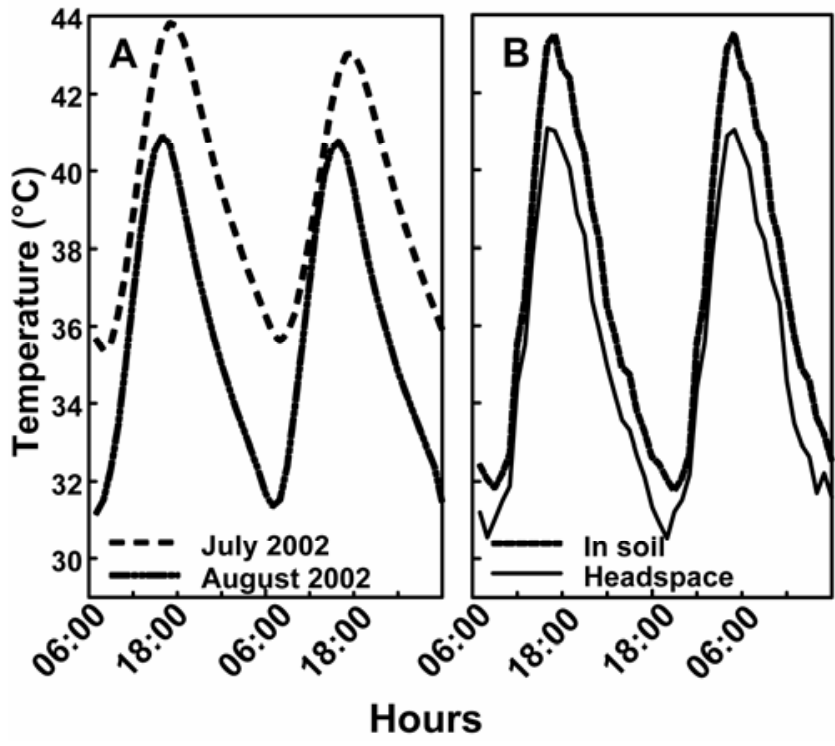

Fig. 2. Soil temperature regime under $\mathbf{A}$, soil solarization at $20 \mathrm{~cm}$ depth, Rehovot, July and August 2002, and B, temperatures in a heated controlled system, recorded at two locations inside the container ( 2 a in Fig. 1): in the soil and in the headspace. Temperatures in the nonsolarized plots ranged from 30 to $33^{\circ} \mathrm{C}$.
The retention time of the peaks appearing on the chromatograms were compared with those of reference compounds that were reported as possible products from rocket leaves $(2,21,27)$.

Determination of soil microbial activity. Hydrolysis of fluorescein diacetate (FDA) was used to assess general enzymatic activity in the experimental soil, essentially as previously described $(7,32,38)$. Soil $(8 \mathrm{~g})$ from each replicate was incubated and shaken in flasks for $30 \mathrm{~min}$ with $50 \mathrm{ml}$ of $60 \mathrm{mM}$ sodium phosphate buffer ( $\mathrm{pH}$ 7.6) in a reciprocal shaker (150 shakes/ min). Subsequently, $0.5 \mathrm{mg}$ of FDA (dissolved in $250 \mu \mathrm{l}$ of acetone) was added to each flask, and the flasks were incubated in the reciprocal shaker for another hour. Samples $(4 \mathrm{ml})$ of each suspension were transferred to a centrifuge tube, and an equal volume of acetone was added to terminate the hydrolytic reaction. The tubes were then centrifuged for $10 \mathrm{~min}$ at 5,000 rpm, and the optical density of the supernatant was determined at $490 \mathrm{~nm}$ by spectrophotometer. The amount of FDA hydrolyzed was calculated from a standard curve of fluorescein concentration (7).

Statistical analyses. All laboratory experiments were carried out at least twice. Data that were taken as percentages were arcsine-transformed before analysis. Separate analyses of each experiment showed homogeneous variances of the experimental error between the replicates. All treatment means were compared simultaneously by Tukey's protected test for significant differences. Statistical analyses in the presented figures and tables show data from one of two experiments. Differences in pathogen control under laboratory conditions were analyzed by comparing area under viability curve of a 28-day period of each treatment. Differences in pathogen control under field conditions and differences in total fungi population were analyzed by comparing CFU numbers at day 28. All analyses were performed with SAS software (SAS Institute, Cary, NC; release 8.01 for PC) at $P \leq 0.05$.

\section{RESULTS}

Soil temperature in the controlled laboratory system and in the field. The range of soil temperature in the controlled system was in the same range as measured during solarization in the field at a depth of $20 \mathrm{~cm}$ during July and August, which are typical months for solarization in Israel and the Mediterranean region (Fig. 2). Daily fluctuations in the soil containers were 31.7 to $43.5^{\circ} \mathrm{C}$ in the soil, and 31.2 to $41.1^{\circ} \mathrm{C}$ in the headspace. The nonheated soil containers were kept at a constant temperature of $25^{\circ} \mathrm{C}$. The maximum temperature measured in the headspace above the soil was 1 to $2^{\circ} \mathrm{C}$ lower than that in the soil, apparently due to differences in heat capacity of the wet soil and the dynamic gas phase in the headspace. Average range of temperatures at $20 \mathrm{~cm}$ was 34.7 to $43^{\circ} \mathrm{C}$ in solarized plots and maximal soil temperatures at depths of 20 and $40 \mathrm{~cm}$ did not exceed 44 and $38^{\circ} \mathrm{C}$, respectively.

The incorporation of dried herb material increased soil temperature in the solarized plots by 1 to $2^{\circ} \mathrm{C}$ (data not shown). Average daily range of temperatures at $20 \mathrm{~cm}$ was 34.3 to $44.4^{\circ} \mathrm{C}$ for thyme-amended soils and 34.9 to $44.6^{\circ} \mathrm{C}$ for wild rocket-amended soils. In the nonsolarized plots, the temperatures were 29.3 to $32.6^{\circ} \mathrm{C}$ (data not shown) and average maximal soil temperatures were 34 and $32^{\circ} \mathrm{C}$ at depths of 20 and $40 \mathrm{~cm}$, respectively, with no difference in temperature between amended and nonamended nonsolarized soils.

Oxygen concentration in the soil atmosphere. The fluctuations in $\mathrm{O}_{2}$ concentration in the soil containers, when a constant air-flow rate of 2.3 to $3.1 \mathrm{ml} / \mathrm{min}$ per container was applied, followed a trend that was generally similar to that observed in the field (Fig. 3). Oxygen concentration in all OA soils, in both the controlled system and the field, decreased sharply during the first 2 days after incorporation. Temporary, virtual anaerobic conditions were created in the soil that was amended with wild rocket, 3 days after incubation (oxygen concentration declining to 0.14 
and $1.7 \%$ at 20 and $40 \mathrm{~cm}$ depth, respectively). In contrast, oxygen concentration in the nonamended soils was not much changed during the 4 weeks of solarization, or heating in containers. Oxygen concentration in the amended soils, in both the field and controlled system, recovered to atmospheric levels 7 days after the start of the experiment.

In the controlled system, in which we maintained anaerobic conditions, oxygen concentration declined rapidly down to $2 \%$ after $6 \mathrm{~h}$ and to below detectable levels after $24 \mathrm{~h}$. The anaerobic conditions were maintained for 4 weeks. Anoxic conditions were observed in nonamended soil during this period, with a decline of $\mathrm{O}_{2}$ concentrations to $5 \%$.

Soil pH. Heating or solarization of amended soil increased soil $\mathrm{pH}$ values, from 8.0 to 8.5 , in both the field and controlled system. Soil amendment without solarization or heating reduced soil pH to 7.5. Solarization of nonamended soil did not affect soil $\mathrm{pH}$ values significantly, whereas soil heating in the controlled system resulted in a moderate reduction of $0.5 \mathrm{pH}$ units, similar to observations in a previous study in the field (16).

Control of soilborne plant pathogens. Propagules of tested pathogens were placed in different locations in the controlled system (Fig. 1). A rapid reduction in chlamydospore viability was observed in the heated treatments (Fig. 4). The reduction in viability was significant in the soil (2a in Fig. 1, Table 1), which was simultaneously exposed to the effects of all components, namely heating, the generated volatile compounds and microbial activity. A similar reduction in $F$. oxysporum f. sp. radicislycopersici viability was observed in the headspace of the soil container (exposed to both volatiles and heating). In the volatile container (2b in Fig. 1), where chlamydospores were exposed only to volatiles, an $86 \%$ reduction in $F$. oxysporum $\mathrm{f}$. sp. radicislycopersici viability was obtained in the treatments that included

\section{Field experiment, $20 \mathrm{~cm}$ depth}

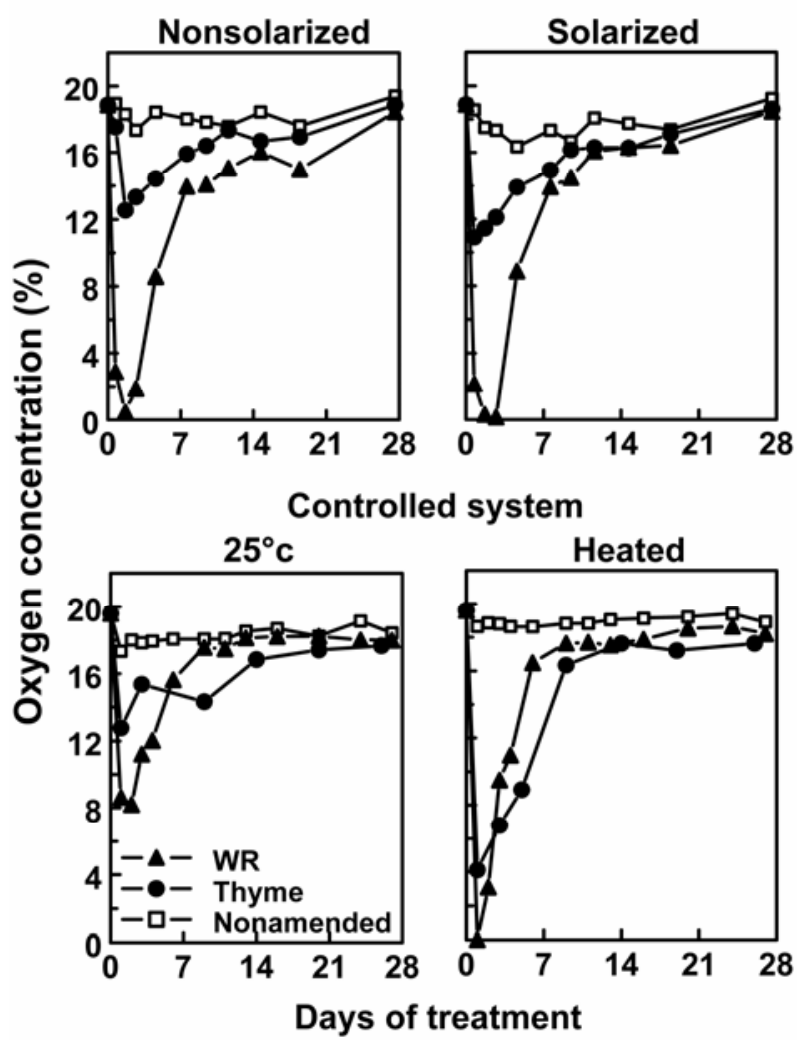

Fig. 3. Effect of soil heating and organic amendments $(\mathrm{WR}=$ wild rocket $)$ on $\mathrm{O}_{2}$ concentration in the soil atmosphere in the field during soil solarization, Rehovot, July 2002, and in soil headspace during soil treatment in the controlled system, applying an air flow of 2.3 to $3.1 \mathrm{ml} / \mathrm{min}$ per container. SD $\max =2.33$ and 3.75 , in the field and in the controlled system, respectively. wild rocket amendment and heating. A pronounced reduction in F. oxysporum f. sp. radicis-lycopersici viability in nonheated soil was observed only with wild rocket amendment under anaerobic conditions. The control of $F$. oxysporum $\mathrm{f}$. sp. radicis-lycopersici under anaerobic conditions in the nonheated system was more pronounced in the headspace than in the volatile container, apparently because exposure to the volatiles in the headspace was more intensive. Under field conditions, amendment of wild rocket or thyme in the nonsolarized plots had only a partial or no effect on pathogen survival (Fig. 5), a trend similar to the controlled system under aerobic conditions. On the other hand, solarization at depths of $20 \mathrm{~cm}$, with or without OA, was highly effective. At $40 \mathrm{~cm}$, the combined treatments were highly effective, as also observed in the controlled system: viability was reduced by 84 and $97 \%$ by solarization combined with wild rocket and solarization combined with thyme, respectively.

Infectivity of $M$. javanica (which, in the controlled system, was only examined in the soil containers) was totally eliminated by both heat and solarization at $20 \mathrm{~cm}$ depth, regardless of soil amendment or soil aeration (Table 2). Solarization at $40 \mathrm{~cm}$ depth was less effective. Root gall incidence in nonamended, and either nonheated or nonsolarized soil, was $100 \%$. In wild rocket- and thyme-amended soils, disease incidence was reduced by 67 and $100 \%$ by solarization at $40 \mathrm{~cm}$ depth, respectively, compared with $67 \%$ in nonamended soil. Wild rocket amendment in nonheated soil or nonsolarized at $20 \mathrm{~cm}$ depth also reduced disease incidence.

Effect of soil solarization and OA on biological activity and microbial populations. In the controlled laboratory system, enzymatic activity was high in OA soil under aerobic conditions, both heated and nonheated, compared with nonamended treatments (Fig. 6). Activity level under anaerobic conditions was, for the most part, similar to that in the nonamended soil. In general, microbial activity in amended soil was determined to be higher when FDA incubation was conducted at $45^{\circ} \mathrm{C}$ than at $25^{\circ} \mathrm{C}$. These trends were also observed in the field, although the microbial activity at the shaded-amended plots was lesser than at the controlled system (Fig. 7). In addition, enzymatic activity was more pronounced in soil amended with wild rocket than with thyme (Fig. 7).

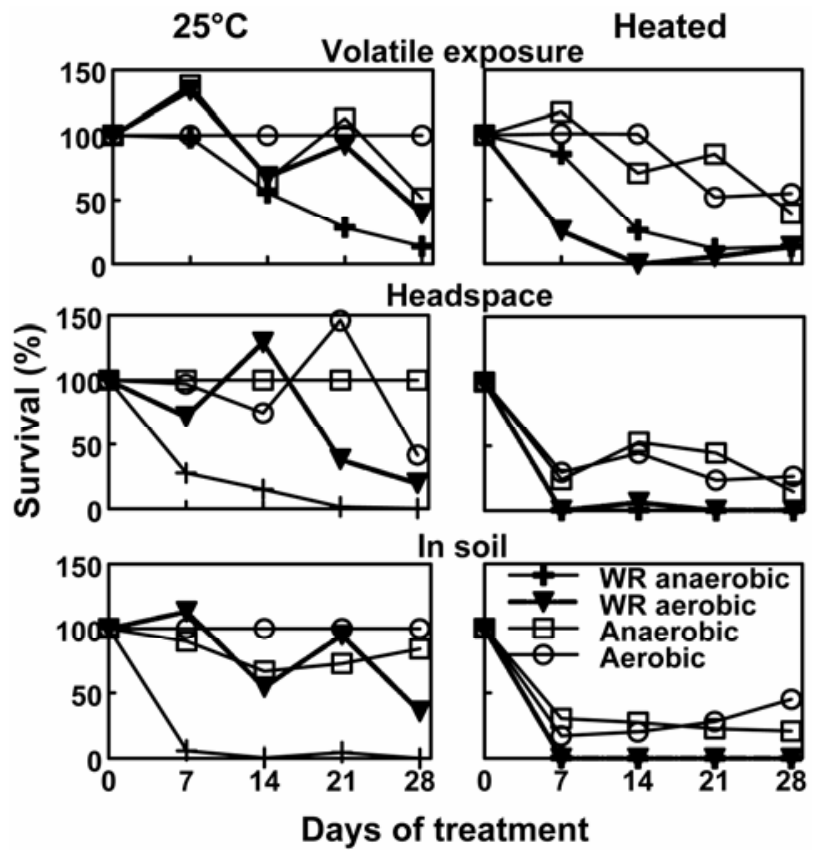

Fig. 4. Effect of soil heating, organic amendment (WR = wild rocket) and location in the containers of the controlled system on the survival of chlamydospores of Fusarium oxysporum f. sp. radicis-lycopersici. SD $\max =124$. 
Wild rocket-amended soil, either solarized or heated under aerobic conditions, exhibited a significant population reduction of total fungi after 28 days by 83 and $95 \%$ compared with shaded nonamended plots and $25^{\circ} \mathrm{C}$ nonamended soil, respectively (Table $3)$. In comparison, wild rocket amendment without solarization did not affect total fungi population, while incubation of wild rocket at $25^{\circ} \mathrm{C}$ significantly increased total fungi by $81 \%$. Under anaerobic conditions in the controlled system (sealed containers) wild rocket amendment with or without heating significantly reduced total fungi by 99 and $95 \%$, respectively, compared with $25^{\circ} \mathrm{C}$ nonamended and aerated control.

Under field conditions, populations of total fungi were significantly reduced by 66 and $83 \%$ by solarization and by solarization with wild rocket amendment, respectively (Table 3 ).

Wild rocket amendment significantly increased populations of total bacteria by 700 to $1,200 \%$ following heating in the controlled system under aerobic conditions or solarization, compared with minor changes in thyme-amended or nonamended soils. Under anaerobic conditions, total bacteria increased by only 100 to $265 \%$, regardless of OA (data not shown).

Effect of soil heating and soil aeration on the generation of volatile compounds in the controlled laboratory system. Soil heating, OA, and aeration of the soil each affected the generation and release of volatile compounds. Under aerobic conditions, Lsulforaphane, a compound with a retention time of $31.9 \mathrm{~min}$ in our system, was the predominant component, constituting $30 \%$ of all volatiles detected. This volatile is a glucosinolate hydrolysis product from Brassica, which has biotoxic and antioxidative features $(2,13,39)$. It was detected in wild rocket-amended, but not nonamended soil (the analysis could not be carried out with thyme), and at higher concentrations in the heated treatments (Fig. 8). The highest amount of L-sulforaphane was produced in the first days of incubation. Heating or OA also increased the production of unidentified volatiles, the highest amounts of these being produced in the heat-amended soil (data not shown). Under anaerobic conditions, maximal values were recorded in the heated-amended soil, apparently due to the accumulation of volatiles in the sealed containers (data not shown). Small amounts of volatile compounds were also generated in the nonamended soil.

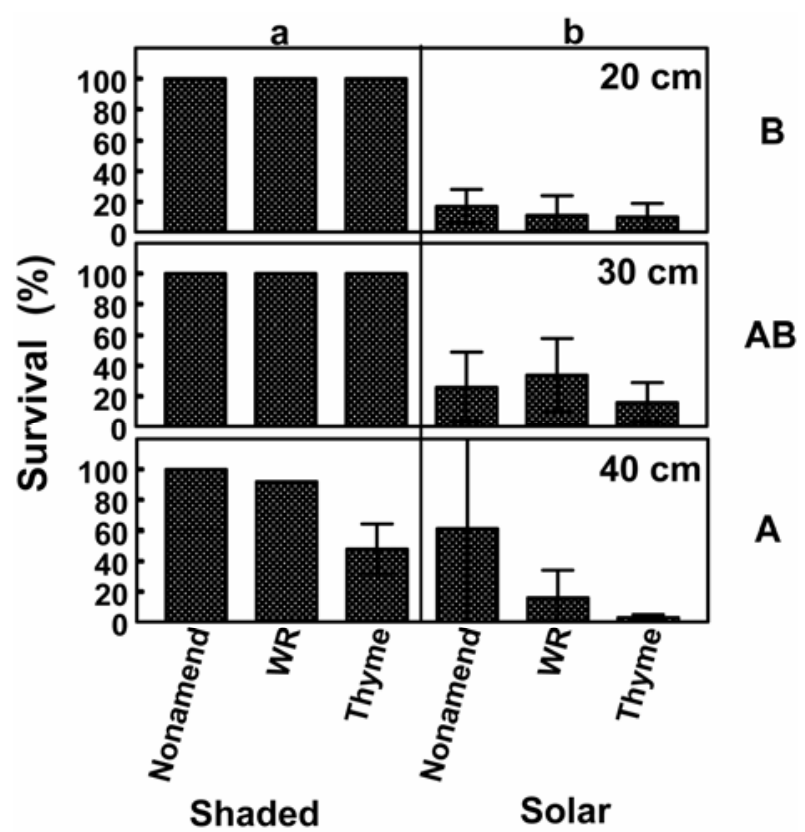

Fig. 5. Effect of soil solarization (solar) and organic amendment (WR = wild rocket) on the survival of chlamydospores of Fusarium oxysporum f. sp. radicis-lycopersici, July 2002, at three soil depths. Shaded: mulched and shaded soil, to prevent heating (mulched control). Bars represent \pm SD. Since no significant interaction was observed, the differences among the main effects are shown. Different uppercase letters denote significant differences among soil depths; lowercase letter denotes significant differences between shaded versus solarized treatments $(P<0.05)$.

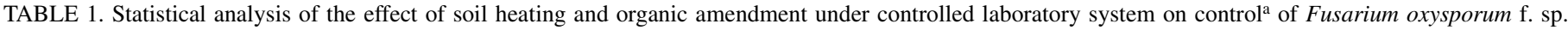
radicis-lycopersici at different locations in the controlled system

\begin{tabular}{|c|c|c|c|c|c|}
\hline \multirow[b]{2}{*}{ Amendment } & \multirow[b]{2}{*}{ Treatment $^{\mathrm{b}}$} & \multirow[b]{2}{*}{ Location $^{\mathrm{c}}$} & \multicolumn{3}{|c|}{ Area under F. oxysporum f. sp. radicis-lycopersici viability curve } \\
\hline & & & Aerated containers $^{d}$ & Sealed containers ${ }^{\mathrm{e}}$ & $\operatorname{MSD}^{\mathrm{f}}$ \\
\hline Nonamended & $25^{\circ} \mathrm{C}$ & Soil container - in soil & 79711 & 65450 & 18922 \\
\hline Rocola & $25^{\circ} \mathrm{C}$ & Soil container - in soil & 69011 & 18656 & 47441 \\
\hline Nonamended & Heated & Soil container - in soil & 31546 & 30848 & 16039 \\
\hline Rocola & Heated & Soil container - in soil & 13684 & 13748 & 12029 \\
\hline Nonamended & $25^{\circ} \mathrm{C}$ & Soil container - above soil & 131820 & 148834 & 175700 \\
\hline Rocola & $25^{\circ} \mathrm{C}$ & Soil container - above soil & 91855 & 30608 & 38481 \\
\hline Nonamended & Heated & Soil container - above soil & 51566 & 52745 & 61181 \\
\hline Rocola & Heated & Soil container - above soil & 15256 & 13812 & 12165 \\
\hline Nonamended & $25^{\circ} \mathrm{C}$ & Volatile exposure container & 85518 & 78797 & 39115 \\
\hline Rocola & $25^{\circ} \mathrm{C}$ & Volatile exposure container & 72252 & 44821 & 29496 \\
\hline Nonamended & Heated & Volatile exposure container & 67311 & 68161 & 34743 \\
\hline Rocola & Heated & Volatile exposure container & 20822 & 34265 & 23649 \\
\hline
\end{tabular}

Analysis of variance of the area under viability curve

\begin{tabular}{|c|c|c|}
\hline Source & df & $F$ value $^{\mathrm{g}}$ \\
\hline Place $^{c}$ & 2 & $6.10^{* *}$ \\
\hline Heating $^{\mathrm{b}}$ & 1 & $43.60^{* * *}$ \\
\hline Amendment & 1 & $35.37^{* * *}$ \\
\hline Aeration $^{\mathrm{d}, \mathrm{e}}$ & 1 & 2.89 \\
\hline Place $\times$ heating ${ }^{\mathrm{h}}$ & 2 & $4.37^{*}$ \\
\hline Heating $\times$ aeration $^{\mathrm{h}}$ & 1 & $4.21^{*}$ \\
\hline
\end{tabular}

a Area under viability curve, after 28 days.

${ }^{\mathrm{b}}$ Constant temperature $\left(25^{\circ} \mathrm{C}\right)$, or heating that simulates solarization regime under laboratory conditions for 28 days.

${ }^{c}$ Different locations at the controlled laboratory system, exposure to different effects, as shown on Figure 1.

d Air flow rate 2 to $3 \mathrm{ml} / \mathrm{min} /$ container.

e Anaerobic conditions

${ }^{\mathrm{f}}$ Minimum significant difference.

g Significant differences were obtained by ${ }^{*} P<0.05,{ }^{* *} P<0.01$, and ${ }^{* * *} P<0.0001$.

h Only statistically significant intereactions are shown. 
No data on volatiles could be collected in the field due to technical difficulties involving their detection.

\section{DISCUSSION}

In the study reported here, we developed and validated an environmentally controlled system that simulates important physical, chemical, and microbial processes taking place in the soil during solarization, either with or without OA. Soil temperature (Fig. 2), $\mathrm{O}_{2}$ concentrations (Fig. 3), pathogen control (Figs. 4 and 5), and microbial activity (Figs. 6 and 7) showed similar patterns in the field and in the controlled system under aerobic conditions. The fluctuations in soil temperature in the controlled system were similar to those recorded in the soil during standard solarization in the Mediterranean region at a depth of $20 \mathrm{~cm}$ (Fig. 2), but the system can be adjusted to different heating regimes, as required. Organic amendment increased soil temperature in the solarized plots by 1 to $2^{\circ} \mathrm{C}$, as has been previously reported (18). Supplying a continuous ultra-low constant air flow through the soil in each container enabled a simulation of the changes in soil atmosphere as they occur in the field, as well as elimination of the aeration problem which usually becomes a limiting factor in closed containers. Other techniques of soil aeration, e.g., chemical oxidation or artificial atmosphere application $(3,19,24)$, involve unwanted effects such as undesirable chemicals, elevated volatile concentrations, or pressure fluctuations. Oxygen concentration in the nonamended soil was not much affected during the 4 weeks of solarization, or in the controlled system, similar to the report by Rubin and Benjamin (31). Following a sharp decline in the amended soil, as in previous reports $(4,37), \mathrm{O}_{2}$ concentration recovered to atmospheric levels after 7 days of solarization (field) or heating in the controlled system. The recovery of $\mathrm{O}_{2}$ concentration may be due to the diffusion of air from deeper soil layers, or through the plastic film (field), or due to the air flow in the controlled system. This recovery was not reported in the study performed by Blok et al. (5), who found stable anaerobic conditions in mulched OA soil for 80 days, using flooding and extreme soil compaction. Oxygen is a key factor in the pathway of OA decomposition in soil through its direct effect on redox potential and microbial activity $(5,24,29,31)$. The low pressure $(<0.001$ bars $)$ applied in our system enabled homogeneous air flow in the soil containers. However, at that level, pressure had no pronounced effect on inoculum viability in the range of temperatures studied (data not shown).

Heating or solarization of amended soil moderately increased its $\mathrm{pH}$ values, as has been observed when biosolids are added to solarized soils (28). Solarization alone did not affect soil $\mathrm{pH}$ significantly, as also found by Chen and Katan (8), whereas heating in the controlled system resulted in a moderate reduction of 0.5 $\mathrm{pH}$ units, similar to that observed in another study in the field (16).
The controlled system enabled us to identify the factors that might be involved in pathogen inactivation due to heating, OA, or both. A rapid reduction in the viability of $F$. oxysporum f. sp. radicis-lycopersici chlamydospores was observed in the heated and amended treatments (Fig. 4), and in the soil in containers which was simultaneously exposed to heating, generation of volatile compounds and microbial activity. Similar results were observed in the field under solarization of amended soil. A sharp reduction in chlamydospore viability was also seen in the headspace of the soil container, which was influenced by the heat and volatile compounds, indicating that in the top layer of soil during solarization, these two effects are the dominant pestinactivation factors. The volatile compounds, which apparently play an important role in pest inactivation in the amended soil, could be separately analyzed in the volatile-exposure containers in our system. This cannot be done in open containers (30). Exposure to volatile compounds alone was effective in reducing fungal viability only with the combined $\mathrm{OA}$ and heating treatment, as also reported in studies involving cabbage amendment and heating (17).

Under aerobic laboratory and field conditions, OA increased FDA hydrolysis. Dissanayake and Hoy (12) found a positive cor-

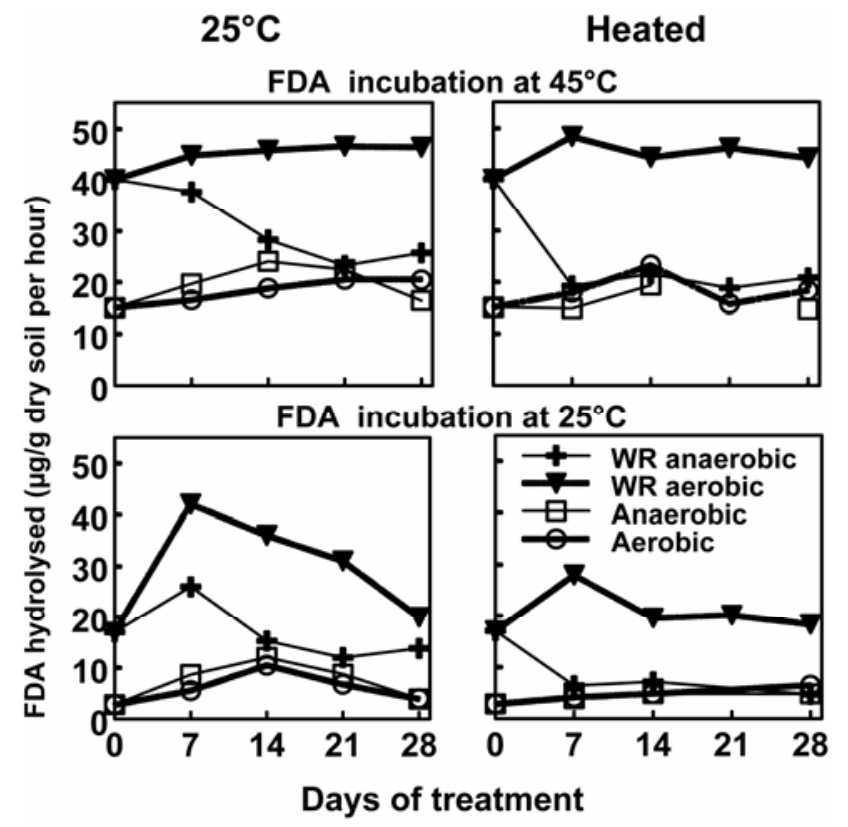

Fig. 6. Effect of soil heating $\left(25^{\circ} \mathrm{C}\right.$ or heated), organic amendment (WR = wild rocket), soil aeration, and incubation temperature $\left(25\right.$ or $\left.45^{\circ} \mathrm{C}\right)$ on enzymatic activity in the soil in the controlled system as determined by fluorescein diacetate (FDA) hydrolysis. SD $\max =10$.

TABLE 2. Effect of organic amendments, soil solarization, or heating in the controlled laboratory system on incidence of galled tomato plants

\begin{tabular}{|c|c|c|c|c|c|c|}
\hline \multirow[b]{3}{*}{ Amendment } & \multicolumn{6}{|c|}{ Galling incidence $(\%)$ under } \\
\hline & \multicolumn{3}{|c|}{ Soil solarization $^{\mathrm{a}}$} & \multicolumn{3}{|c|}{ Controlled system ${ }^{b}$} \\
\hline & Treatment & Depth $20 \mathrm{~cm}$ & Depth $40 \mathrm{~cm}$ & Treatment & Aerated containers ${ }^{\mathrm{c}}$ & Sealed containers ${ }^{\mathrm{d}}$ \\
\hline Nonamended & Shaded & $100 \pm 0^{\mathrm{e}}$ & $100 \pm 0$ & $25^{\circ} \mathrm{C}$ & $100 \pm 0$ & $100 \pm 0$ \\
\hline Wild rocket & Shaded & $33 \pm 58$ & $100 \pm 0$ & $25^{\circ} \mathrm{C}$ & 0 & $33 \pm 58$ \\
\hline Thyme & Shaded & $100 \pm 0$ & $100 \pm 0$ & $25^{\circ} \mathrm{C}$ & $\mathrm{Nt}^{\mathrm{f}}$ & $\mathrm{Nt}$ \\
\hline Nonamended & Solarized & 0 & $33 \pm 58$ & Heated & 0 & 0 \\
\hline Wild rocket & Solarized & 0 & $33 \pm 58$ & Heated & 0 & 0 \\
\hline Thyme & Solarized & 0 & $0 \pm 0$ & Heated & $\mathrm{Nt}$ & $\mathrm{Nt}$ \\
\hline
\end{tabular}

a Solarization or shading under field conditions was conducted for 28 days during July 2002.

${ }^{\mathrm{b}}$ Constant temperature $\left(25^{\circ} \mathrm{C}\right)$ or heating to simulate the solarization regime under laboratory conditions for 28 days.

c Air-flow rate: 2 to $3 \mathrm{ml} / \mathrm{min}$ per container.

d Anaerobic conditions.

e Value \pm SD.

${ }^{\mathrm{f}} \mathrm{Nt}=$ not tested. 
relation between FDA hydrolysis in amended soil and pathogen control. In general, microbial activity in amended soil was higher at the $45^{\circ} \mathrm{C}$ incubation than at $25^{\circ} \mathrm{C}$, indicating a possible increase in the activity of thermo-tolerant microorganisms, similar to the findings of Yarden et al. (38). Activity under anaerobic conditions decreased to those levels found in nonamended soils, in agreement with previous work using a sealed laboratory system (17). A combination of soil solarization and anaerobic conditions improved pathogen control (Fig. 4), as also found by Blok et al. (5).

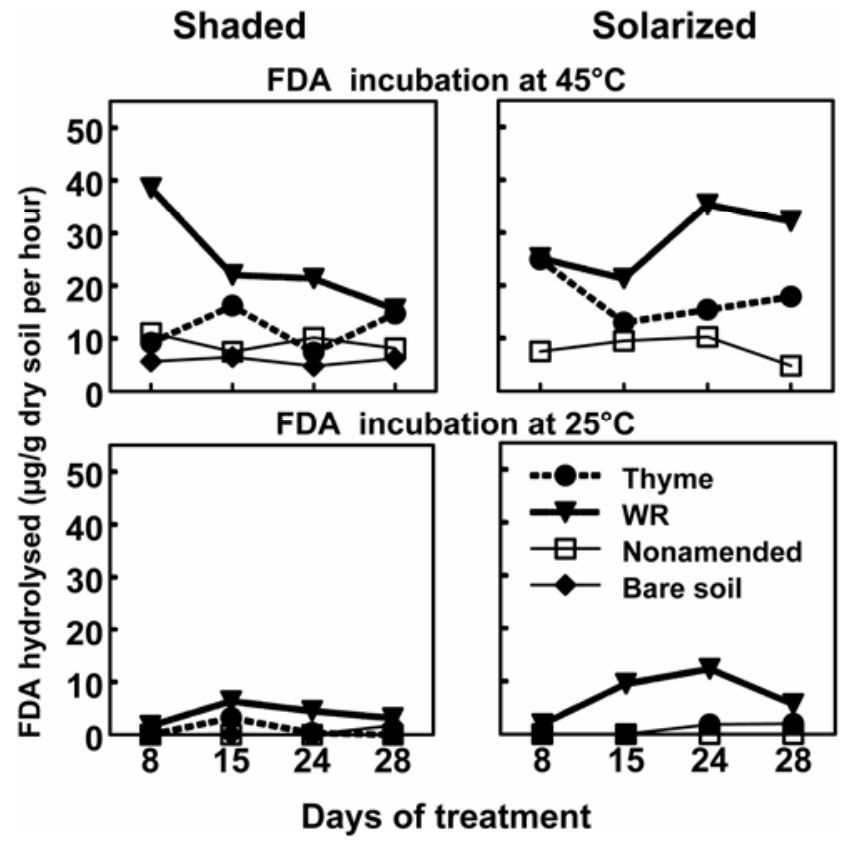

Fig. 7. Effect of soil solarization (solarized or shaded), organic amendment (WR = wild rocket), and incubation temperature $\left(25\right.$ or $\left.45^{\circ} \mathrm{C}\right)$ on enzymatic activity in the soil as determined by fluorescein diacetate (FDA) hydrolysis. Shaded: mulched and shaded soil, to prevent heating (mulched control). Bare soil: nonmulched nonshaded and nonamended soil. SD $\max =18$.
However, constant anaerobic conditions do not prevail in the field unless extreme soil compaction and flooding are applied.

Although both solarization and heating, of amended soil reduced the number of total fungi, a more pronounced effect was obtained in the laboratory system (Table 3). A significant reduction in fungal population was obtained in amended soil under anaerobic conditions, irrespective of heating. Total bacteria were increased by $500 \%$ following heating of wild rocket-amended soils, under both field and laboratory conditions, compared with minor changes in the thyme-amended or nonamended soils, or under anaerobic conditions. Enhancement of the total bacterial

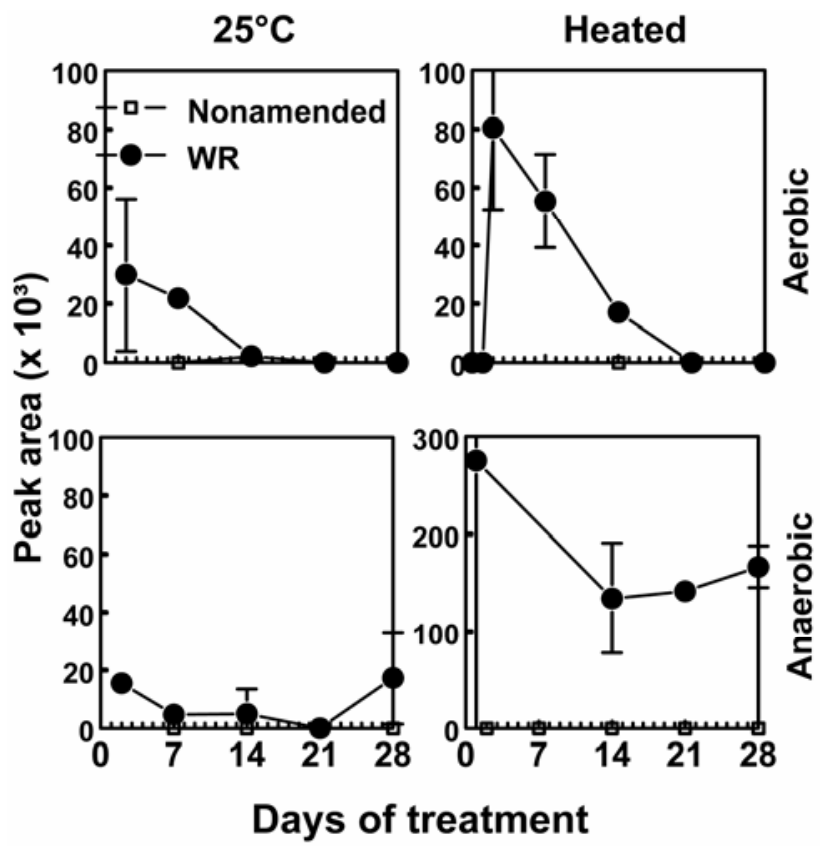

Fig. 8. Effect of soil heating, organic amendment, and aeration in the controlled system on the release of L-sulforaphane in the soil headspace, expressed as peak area. Bars represent \pm SD.

TABLE 3. Effect of soil solarization at $20 \mathrm{~cm}$ depth, or heating in the controlled laboratory system for 28 days, and organic amendments on total fungal population

\begin{tabular}{|c|c|c|c|c|c|}
\hline \multirow[b]{3}{*}{ Amendment } & \multicolumn{5}{|c|}{ Total fungi $10^{3} \mathrm{CFU} / \mathrm{g}$ dry soil } \\
\hline & \multicolumn{2}{|c|}{ Soil solarization ${ }^{\mathrm{a}}$} & \multicolumn{3}{|c|}{ Controlled system ${ }^{\mathrm{a}}$} \\
\hline & Treatment $^{\mathrm{b}}$ & $\mathrm{CFU} / \mathrm{g}(20 \mathrm{~cm})$ & Treatment $^{\mathrm{c}}$ & Aerated containers ${ }^{\mathrm{d}}$ & Sealed containers ${ }^{\mathrm{e}}$ \\
\hline Wild rocket & Shaded & $13.6 \pm 2.6$ & $25^{\circ} \mathrm{C}$ & $25.0 \pm 3.5$ & $0.7 \pm 0.1$ \\
\hline Thyme & Shaded & $10.0 \pm 14.5$ & $25^{\circ} \mathrm{C}$ & $\mathrm{Nt}^{\mathrm{g}}$ & $\mathrm{Nt}$ \\
\hline Nonamended & Solarized & $7.4 \pm 0.9$ & Heated & $14.1 \pm 0.6$ & $14.4 \pm 0$ \\
\hline Wild rocket & Solarized & $3.7 \pm 2.7$ & Heated & $0.7 \pm 0.9$ & $0.2 \pm 0$ \\
\hline
\end{tabular}

Analysis of variance of CFU

\begin{tabular}{lcc}
\hline Source & df & $F$ value $^{\mathrm{h}}$ \\
\hline Heat $^{\mathrm{c}}$ & 1 & 87.9 \\
Amend $_{\text {Aeration }}^{\mathrm{d}, \mathrm{e}}$ & 1 & 130.9 \\
Heat $\times$ amend & 1 & 72.2 \\
Heat $\times$ aeration & 1 & 80.1 \\
Amend $\times$ aeration & 1 & 69.3 \\
Heat $\times$ amend $\times$ aeration & 1 & 96.1 \\
\hline
\end{tabular}

a Population density as assayed on day 0 was $9.0 \pm 1.8 \mathrm{CFU} / \mathrm{g}$ dry soil.

${ }^{\mathrm{b}}$ Solarization or shading under field conditions was conducted for 28 days during July 2002.

${ }^{\mathrm{c}}$ Constant temperature $\left(25^{\circ} \mathrm{C}\right)$ or heating to simulate the solarization regime under laboratory conditions for 28 days.

d Air-flow rate: 2 to $3 \mathrm{ml} / \mathrm{min}$ per container.

e Anaerobic conditions.

${ }^{\mathrm{f}}$ Value $\pm \mathrm{SD}$. The shaded treatments are significantly different from the solarized.

${ }^{\mathrm{g}} \mathrm{Nt}=$ not tested.

h Significant differences were obtained by $P<0.0001$. 
population by OA, with or without solarization, has been observed in previous works $(30,33,34)$.

L-Sulforaphane was the predominant volatile detected in the wild rocket-amended soil, at a higher rate during the first week of incubation, and at higher concentrations in the heated treatments (Fig. 8). This volatile has been found to be toxic (13), but other volatile compounds that are generated upon OA decomposition can also affect pathogens and soil microflora $(17,25,30)$. The controlled system enables an identification of the direct effects of volatiles on pathogens as well as their indirect effect, by enhancing antagonistic soil microflora.

The present system, under controlled aerobic conditions, reasonably simulates the processes that take place in the field, including temperature fluctuations, changes in soil atmosphere, microbial activity, and pathogen inactivation. Obviously, unlike field conditions, the controlled system enables better control of each parameter and the effects can therefore be intensified if necessary, uniformly maintained, or studied separately. The system presented here can serve two important objectives: to study each process in the soil separately, and to evaluate the effects of OA, alone or combined with solarization, in terms of its potential control of soilborne pests.

\section{ACKNOWLEDGMENTS}

We thank the staff of the Laboratory for Pest Management Research for their technical assistance; M. Alpert and YAAF corporation at Mehola village, for providing fresh herbs; SHORASHIM and HISHTIL nurseries, for providing seedlings; Y. Grinspon, for electronic engineering; $M$. Barak, for technical advice; H. Voet for advice in the statistical analysis; and Y. Gotlieb and the staff of the Hebrew University Experimental Farm for their cooperation. This research was partially supported by grants from the Chief Scientist of the Ministry of Agricultural and Rural Development. Contribution No. 708/06 series from the Agricultural Research Organization, The Volcani Center, Bet Dagan, Israel.

\section{LITERATURE CITED}

1. Austerweil, M., Steiner, B., and Gamliel, A. 2006. Permeation of soil fumigants through agricultural plastic films. Phytoparasitica 34:491-501.

2. Bennett, R. N., Rosa, E. A. S., Mellon, F. A., and Kroon P. A. 2006. Ontogenic profiling of glucosinolates, flavonoids, and other secondary metabolites in Eruca sativa (salad rocket), Diplotaxis erucoides (wall rocket), Diplotaxis tenuifolia (wild rocket), and Bunias orientalis (Turkish rocket). J. Agric. Food Chem. 54:4005-4015.

3. Beute, M. K., and Rodriguez-Kabana, R. 1979. Effect of volatile compounds from remoistened plant tissues on growth and germination of sclerotia of Sclerotium rolfsii. Phytopathology 69:802-805.

4. Birch, H. F. 1959. Further observations on humus decomposition and nitrification. Plant Soil 11:262-286.

5. Blok, W. J., Lamers, J. G., Termorshuizen, A. J., and Bollen, G. J. 2000. Control of soilborne plant pathogens by incorporating fresh organic amendments followed by tarping. Phytopathology 90:253-259.

6. Brown, P. D., and Morra, M. J. 1997. Control of soilborne plant pests using glucosinolate containing plants. Adv. Agron. 61:167-231.

7. Chen, W., Hoitink, H. A. J., Schmitthenner, A. F., and Tuovinen, O. L. 1988. The role of microbial activity in suppression of damping-off caused by Pythium ultimum. Phytopathology 78:314-322.

8. Chen, Y., and Katan, J. 1980. Effect of solar heating of soils by transparent polyethylene mulching on their chemical properties. Soil Sci. 130:271-276.

9. Conn, K. L., and Lazarovits, G. 1999. Impact of animal manures on Verticillium wilt, potato scab and soil microbial populations. Can. J. Plant Pathol. 21:81-92.

10. Daferera, D. J., Ziogas, B. S., and Polissiou, M. G. 2003. The effectiveness of plant essential oils on the growth of Botrytis cinerea, Fusarium sp. and Clavibacter michiganensis subsp. michiganensis. Crop Prot. 22:39-44.

11. Dhingra, O. D., and Sinclair, J. B. 1995. Page 393 in: Basic Plant Pathology Methods. 2nd ed. CRC Press, Boca Raton, FL.

12. Dissanayake, N., and Hoy, J. W. 1999. Organic material soil amendment effects on root rot and sugarcane growth and characterization of the materials. Plant Dis. 83:1039-1046.

13. Fahey, J. W., Haristoy, X., Dolan, P. M., Kensler, T. W., Scholtus, I., Stephenson, K. K., Talalay, P., and Lozniewski, A. 2002. Sulforaphane inhibits extracellular, intracellular and antibiotic-resistant strains of Helicobacter pylori and prevents benzo[a]pyrene-induced stomach tumors. Proc. Natl. Acad. Sci. USA 99:7610-7615.

14. Freeman, S., and Katan, J. 1988. Weakening effect of propagules of Fusarium by sublethal heating. Phytopathology 78:1656-1661.

15. Gamliel, A., Austerweil, M., and Kritzman, G. 2000. Nonchemical approach to soilborne pest management-organic amendments. Crop Prot. 19:847-853.

16. Gamliel, A., and Katan, J. 1991. Involvement of fluorescent pseudomonads and other microorganisms in increased growth response of plants in solarized soils. Phytopathology 81:494-502.

17. Gamliel, A., and Stapleton, J. J. 1993. Characterization of antifungal volatile compounds evolved from solarized soil amended with cabbage residues. Phytopathology 83:899-905.

18. Gamliel, A., and Stapleton, J. J. 1993. Effect of chicken compost or ammonium phosphate and solarization on pathogen control, rhizosphere microorganisms and lettuce growth. Plant Dis. 77:886-891.

19. Greenberger, A., Yogev, A., and Katan, J. 1987. Induced suppressiveness in solarized soils. Phytopathology 77:1663-1667.

20. Huie, C. W. 2002. A review of modern sample-preparation techniques for the extraction and analysis of medicinal plants. Anal. Bioanal. Chem. 373:23-30

21. Jirovets, L., Smith, D., and Buchbauer, G. 2002. Aroma compound analysis of Eruca sativa (Brassicaceae) SPME headspace leaf samples using GC, GC-MS, and Olfactometry. J. Agric. Food Chem. 50:4643-4646.

22. Katan, J., and DeVay, J. E. (eds.) 1991. Soil Solarization. CRC Press, Boca Raton, FL

23. King, E. O., Ward, M. K., and Raney, D. E. 1954. Two simple media for the demonstration of pyoacin and fluorescin. J. Lab. Clin. Med. 44:301-307.

24. Kirchmann, H., and Witter, E. 1989. Ammonia volatilization during aerobic and anaerobic manure decomposition. Plant Soil 115:35-41.

25. Linderman, R. G., and Gilbert, R. G. 1975. Influence of volatiles of plant origin on soil-borne plant pathogens. Pages 90-99 in: Biology and Control of Soil-Borne Plant Pathogens. G. W. Bruehl, ed. American Phytopathological Society, St. Paul, MN.

26. Marino, M., Bersani, C., and Comi, G. 1999. Antimicrobial activity of the essential oils of Thymus vulgaris $\mathrm{L}$. measured using bioimpedometric method. J. Food Prot. 62:1017-1023.

27. Miyazawa, M., Maehara, T., and Kurose, K. 2002. Composition of the essential oil from the leaves of Eruca sativa. Flavour Fragr. J. 17:187-190.

28. Ozores-Hampton, M., Stanely, P. A., McSorley, R., and Obreza, T. A. 2005. Effects of long term organic amendments and soil solarization on pepper and watermelon growth yield and soil fertility. HortScience 40:8084.

29. Punja, Z. K., and Jenkins, S. F. 1984. Influence of temperature, moisture, modified gaseous atmosphere, and depth in soil on eruptive sclerotial germination of Sclerotium rolfsii. Phytopathology 74:749-754.

30. Ramirez-Villapudua, J., and Munnecke, D. E. 1988. Effect of solar heating and soil amendments of cruciferous residues on Fusarium oxysporum f. sp. conglutinans and other organisms. Phytopathology 78:289295.

31. Rubin, B., and Benjamin, A. 1984. Solar heating of the soil: Involvement of environmental factors in the weed control process. Weed Sci. 32:138-142.

32. Schnurer, J., and Rosswall, T. 1982. Fluorescein diacetate hydrolysis as a measure of total microbial activity in soil and litter. Appl. Environ. Microbiol. 43:1256-1261.

33. Smolinska, U. 2000. Survival of Sclerotium cepivorum sclerotia and Fusarium oxysporum chlamydospores in soil amended with cruciferous residues. Phytopathology 148:343-349.

34. Stevens, C., Khan, V. A., Rodriguez Kabana, R., Ploper, L. D., Backman, P. A., Collins, D. J., Brown, J. E., Wilson, M. A., and Igwegbe, C. K. 2003. Integration of soil solarization with chemical, biological, and cultural control for the management of soilborne diseases of vegetables. Plant Soil 253:493-506.

35. Suhr, K. I., and Nielsen, P. V. 2003. Antifungal activity of essential oils evaluated by two different application techniques against rye bread spoilage fungi. J. Appl. Microbiol. 94:665-674.

36. Triky-Dotan, S., Austerweil, M., Steiner, B., Peretz-Alon, Y., Katan, J., and Gamliel, A. 2007. Generation and dissipation of methyl isothiocyanate in soils following metam sodium fumigation: Impact on Verticillium control and potato yield. Plant Dis. 91:497-503.

37. Van Cleemput, O., El-Sebaay, A. S., and Baert, L. 1983. Evolution of gaseous hydrocarbons from soil: Effect of moisture content and nitrate level. Soil Biol. Biochem. 15:519-524.

38. Yarden, O., Gamliel, A., Aharonson, N., and Katan, J. 1989. Solarization enhances dissipation of carbendazim (MBC) in soil. Soil Biol. Biochem. 21:857-861.

39. Zhang, Y., Talalay, P., Cho, C. G., and Posner, G. H. 1992. A major inducer of anticarcinogenic protective enzymes from broccoli: Isolation and elucidation of structure. Proc. Natl. Acad. Sci. USA 89:2399-2403. 